OPEN ACCESS

Edited by:

Alexander John MacRobert, University College London, United Kingdom

Reviewed by: Franziska Eckert, Tübingen University Hospital, Germany

Bruce Loveland,

Burnet Institute, Australia

*Correspondence:

Pengyu Chang

changpengyu@jlu.edu.cn

tThese authors have contributed equally to this work

Specialty section

This article was submitted to Cancer Immunity and Immunotherapy, a section of the journal

Frontiers in Immunology

Received: 19 January 2020 Accepted: 30 April 2020 Published: 28 May 2020

Citation:

Guo L, Wang C, Qiu X, Pu X and Chang P (2020) Colorectal Cancer Immune Infiltrates: Significance in

Patient Prognosis and

Immunotherapeutic Efficacy.

Front. Immunol. 11:1052 doi: 10.3389/fimmu.2020.01052

\section{Colorectal Cancer Immune Infiltrates: Significance in Patient Prognosis and Immunotherapeutic Efficacy}

\author{
Liang Guo ${ }^{1 \dagger}$, Chuanlei Wang ${ }^{2 \dagger}$, Xiang Qiu ${ }^{3}$, Xiaoyu $\mathrm{Pu}^{4}$ and Pengyu Chang ${ }^{4,5,6 *}$ \\ ${ }^{1}$ Department of Pathology, The First Hospital of Jilin University, Changchun, China, ${ }^{2}$ Department of Hepatobiliary Pancreatic \\ Surgery, The First Hospital of Jilin University, Changchun, China, ${ }^{3}$ Department of Radiology, The First Hospital of Jilin \\ University, Changchun, China, ${ }^{4}$ Department of Radiation Oncology and Therapy, The First Hospital of Jilin University, \\ Changchun, China, ${ }^{5}$ Jilin Provincial Key Laboratory of Radiation Oncology and Therapy, The First Hospital of Jilin University, \\ Changchun, China, ${ }^{6}$ Key Laboratory of Organ Regeneration and Transplantation of the Ministry of Education, Department of \\ Radiation Oncology and Therapy, The First Hospital of Jilin University, Changchun, China
}

Colorectal cancer occurrence and progression involve multiple aspects of host immune deficiencies. In these events, immune cells vary their phenotypes and functions over time, thus enabling the immune microenvironment to be "tumor-inhibiting" as well as "tumor-promoting" as a whole. Because of the association of tumoricidal T cell infiltration with favorable survival in cancer patients, the Immunoscore system was established. Critically, the tumoral Immunoscore serves as an indicator of CRC patient prognosis independent of patient TNM stage and suggests that patients with high Immunoscores in their tumors have prolonged survival in general. Accordingly, stratifications according to tumoral Immunoscores provide new insights into CRC in terms of comparing disease severity, forecasting disease progression, and making treatment decisions. An important application of this system will be to shed light on candidate selection in immunotherapy for $\mathrm{CRC}$, because the $\mathrm{T}$ cells responsible for determining the Immunoscore serve as responders to immune checkpoint inhibitors. However, the Immunoscore system merely provides a standard procedure for identifying the tumoral infiltration of cytotoxic and memory T cells, while information concerning the survival and function of these cells is still absent. Moreover, other infiltrates, such as dendritic cells, macrophages, and B cells, can still influence $\mathrm{CRC}$ prognosis, implying that those might also influence the therapeutic efficacy of immune checkpoint inhibitors. On these bases, this review is designed to introduce the Immunoscore system by presenting its clinical significance and application in $\mathrm{CRC}$.

Keywords: colorectal cancer, immunotherapy, cancer immune milieu, lymphocyte, cancer prognosis

\section{INTRODUCTION}

Colorectal cancer (CRC) is a cancer with a high incidence in industrialized countries. Epigenetic and genetic events are inherently involved in CRC pathogenesis (1). In addition, habits and customs also influence this process, such as a high-fat diet, excessive intake of red meat, smoking, and drinking. Currently, surgery, radiotherapy, and systematic therapy have become the standards of care for CRC patients $(2,3)$. With the introduction of these approaches, a multidisciplinary treatment decision can be made to manage CRC patients, and most patients can benefit from 
comprehensive therapies. As such, the 5-year survival rate of CRC patients has reached over $50 \%$ in most regions worldwide (4).

Traditionally, the TNM staging system is the most available tool for comparing disease severity and predicting the prognosis of CRC. As more advances and insights into CRC heterogeneity and molecular characteristics are gained, other indexes have been introduced to discriminate CRC prognosis, such as RAS or BRAF mutations, and the microsatellite status in tumors (5). More comprehensively, the molecular subtypes of CRC have been stratified by using next-generation sequencing (NGS) technology (6). Accordingly, the CRC patients in each subtype differ in their prognoses (6). Beyond a doubt, profiling of the CRC molecular characteristics will enable treatment decisions to be more precisely and personally made. However, currently, there is still a lack of valid evidence suggesting that NGS-based CRC diagnosis and treatment will improve the prognosis of patients.

Beyond identifying the molecular events occurring in tumor cells, more efforts have been made in profiling the tumor microenvironment in recent years. Herein, characterizing the immune status of tumors is more attractive, because cancer occurrence and progression exhibit a high association with deficiencies, such as immune defense, immune surveillance, and immune homeostasis. In the published studies, several methods concerning the identification of CRC immune status have been established, such as calculating the derived neutrophil to lymphocyte ratio (dNLR) (7), determining the Crohn's-like lymphoid reaction, peritumoral lymphocytic reaction, and intratumoral periglandular reaction plus the density of TILs (8), and evaluating the tumoral Immunoscore (9). Among them, the Immunoscore system is the most reliable because several lines of evidence have revealed that tumoral Immunoscores can independently determine CRC prognosis (9). Based on the ability of the T cell subsets, including Th1, cytotoxic T, and memory $\mathrm{T}$ cells, to cause tumor shrinkage, the densities of $\mathrm{CD}^{+}{ }^{+} \mathrm{CD} 45 \mathrm{RO}^{+}$ memory $\mathrm{T}$ cells and $\mathrm{CD}^{+} \mathrm{CD} 8^{+}$cytotoxic $\mathrm{T}$ cells either in the tumor center (CT) or in the tumor invasive margin (IM) were included into this system (9). Herein, if any region is strongly positive for memory $\mathrm{T}$ cells or cytotoxic $\mathrm{T}$ cells, senior pathologists will assign a score of 1 , thus enabling Immunoscores to reach $0-4$ points (9). In addition to predicting CRC prognosis, the system requires less techniques and costs; thus, clinicians

\footnotetext{
Abbreviations: CRC, colorectal cancer; NGS, next-generation sequencing; dNLR, derived neutrophil to lymphocyte ratio; TIL, tumor-infiltrating lymphocyte; IM, tumor invasive margin; CT, tumor center; MSI, microsatellite instability; dMMR, deficient mismatch repair; DFS, disease-free survival; OS, overall survival; MSS, microsatellite stability; nCRT, neoadjuvant chemoradiotherapy; LARC, local advanced rectal cancer; pCR, pathological complete remission; cCR, clinical complete remission; GZMB, granzyme B; FasL, fas ligand; sIgA, secretory IgA; sIgM, secretory IgM; Breg, regulatory B cells; MDSCs, myeloid-derived suppressive cells; NK, natural killer; DC, dendritic cell; pDC, plasmacytoid dendritic cell; cDC, conventional dendritic cell; PGE2, prostaglandin-E2; IDO, indoleamine2,3-dioxygenase; TAM, tumor-associated macrophages; LPS, lipopolysaccharide; TLR4, toll-like receptor 4; CRCLM, colorectal cancer liver metastasis; CT, center region of tumor; mCRC, metastatic colorectal cancer; DSS, diseasespecific survival; RFS, relapse-free survival; IHC, immunohistochemical staining technology; PCR, polymerase chain reaction technology; TRG, tumor remission grade; VELIPI, venous emboli and lymphatic and perineural invasion.
}

and pathologists recommend it as a routine evaluation for CRC patients in the clinical setting (9).

Immunotherapy has opened a new era of cancer treatment. The therapeutic efficacies of immune checkpoint inhibitors targeting PD-1, PD-L1, and CTLA- 4 are being investigated across cancers. Also being explored are the microsatellite instability (MSI) and deficient mismatch repair (dMMR) statuses, which appear to be credible biomarkers for selecting CRC patients who will benefit from immune checkpoint inhibition $(10,11)$. Critically, the $\mathrm{T}$ cells represented in the Immunoscore system have tumoricidal functions, and they serve as responders to immune checkpoint inhibitors due to their positive expression of PD-1 or CTLA-4. In this regard, can the Immunoscore become a biomarker for candidate selection in immunotherapy? Current data indicate that evaluating $\mathrm{T}$ and $\mathrm{B}$ cell densities in CRC tumors exhibits higher accuracy than evaluating PD-L1 expression in predicting the effectiveness of immunotherapy (12), because PDL1 can be heterogeneously expressed within diverse regions of a tumor (12). Moreover, especially in metastatic CRC, the lesions can have variable Immunoscores (12). Meanwhile, other immune infiltrates, such as Tregs, dendritic cells, and macrophages, might also influence the immune landscape in a CRC tumor (13). This is merely a pitfall of the Immunoscore system. In this review, we will discuss all of the aforementioned issues.

\section{IMMUNOSCORE: AN INDEPENDENT FACTOR DETERMINING CRC PROGNOSIS}

Tumoral infiltration of $\mathrm{T}$ cells has been to be a prognostic factor across several cancers (14). In the past two decades, studies have confirmed the association of high densities of $\mathrm{CD} \mathrm{CT}^{+} \mathrm{IM}^{+}, \mathrm{CD} 45 \mathrm{ROCT}^{+} \mathrm{IM}^{+}, \mathrm{GZMBCT}^{+} \mathrm{IM}^{+}$(granzyme $\mathrm{B}$, a hallmark of cytotoxic $\mathrm{T}$ cells), and $\mathrm{CD} 8 \mathrm{CT}^{+} \mathrm{IM}^{+} \mathrm{T}$ cells with prolonged disease-free survival (DFS) and overall survival (OS) of patients with localized CRC (15-19) (Table 1). In addition, Immunoscores can be used to predict the prognosis of CRC patients with metastases. As with primary tumors, metastatic tumors with 3-4 points predict CRC patients with better prognosis than those tumors with $0-2$ points (20). Alternatively, calculating primary and metastatic tumor Immunoscores jointly will be more precise in predicting CRC prognosis than calculating the score in one site (24). However, recent studies have confirmed that metastatic tumors commonly differ from each other, even in the same patient, suggesting that the metastatic tumor possessing the lowest score determines the DFS of the patient $(12,21)$.

The above data specify the basic role of the Immunoscore in predicting CRC prognosis. Here, the clinical significance of the Immunoscore in CRC prognosis determination is addressed. In order to illustrate this issue, we should take the MSI phenotype as a comparison, because this phenotype has been reported to be the immune subtype of CRC (6). In theory, CRC tumors with MSI phenotypes commonly possess high densities of tumoricidal $\mathrm{T}$ cells due to the abundance of neoantigens from frequent frame-shift mutations occurring in tumor cells (25). Moreover, prospective studies have confirmed the therapeutic effects of immune checkpoint inhibitors on metastatic CRC with the MSI 


\begin{tabular}{|c|c|c|c|c|c|c|}
\hline Author (Ref) & $\begin{array}{l}\text { Cancer } \\
\text { location }\end{array}$ & $\begin{array}{l}\text { TNM- } \\
\text { stage }\end{array}$ & $\begin{array}{l}\text { Sample } \\
\text { size }\end{array}$ & Method & Main results & $\begin{array}{l}\text { Multivariant analysis for the independence } \\
\text { of Immunoscore }\end{array}$ \\
\hline Pagès et al. (15) & $\begin{array}{l}\text { Colon } \\
\text { cancer }\end{array}$ & I-III & 2,681 & $\begin{array}{l}\mathrm{IHC} \text { for CD3 plus CD8 either in CT } \\
\text { and in IM }\end{array}$ & $\begin{array}{l}\text { 1. The risk of recurrence at } 5 \text { years: } 8 \% \text { (high score group) vs. } \\
19 \% \text { (intermediate score group) vs. } 32 \% \text { (low score group) }\end{array}$ & $\begin{array}{l}\text { Immunoscore: A prognostic factor in prediction } \\
\text { of DFS and OS independent of the } \\
\text { parameters }{ }^{A}\end{array}$ \\
\hline Mlecnik et al. (19) & $\mathrm{CRC}$ & $|-|||$ & 599 & $\begin{array}{l}\text { IHC for CD45RO, CD8, CD3, and } \\
\text { GZMB in tumor }\end{array}$ & $\begin{array}{l}\text { 1. Patients with low density of } \mathrm{CD} 8^{+} \mathrm{T} \text { cells in their tumors have } \\
\text { higher risk of relapse than those with high density of } \mathrm{CD} 8^{+} \mathrm{T} \\
\text { cells. } \\
\text { 2. } \mathrm{CD} 8^{+} \mathrm{T} \text { cells density in tumors inversely correlates with T-stage. }\end{array}$ & $\begin{array}{l}\text { Immunoscore: A prognostic factor in prediction } \\
\text { of DFS, DSS, and OS independent of the } \\
\text { parameters }{ }^{B}\end{array}$ \\
\hline \multirow[t]{2}{*}{ Pagès et al. (18) } & CRC & $1-11$ & 29 & $\begin{array}{l}\text { PCR for genes related to memory T, } \\
\text { CD8 cytotoxic T, Th1 and Th2 } \\
\text { orientation, inflammation, } \\
\text { immunosuppression, and } \\
\text { angiogenesis }\end{array}$ & $\begin{array}{l}\text { 1. Tumors with high densities of CD45RO+ cells show higher } \\
\text { expressions of genes encoding CD8, GZMA, GZMK, perforin, } \\
\text { T-bet, IFN- } \gamma \text {, IL12, and IL-18 than those with low density of } \\
\text { CD45RO cells. } \\
\text { 2. Tumors with high densities of CD45RO }{ }^{+} \text {cells show lower } \\
\text { expressions of genes associated with inflammation, Th2 } \\
\text { orientation, and angiogenesis. }\end{array}$ & $\begin{array}{l}\text { Both Immunoscore and bowel perforation are } \\
\text { independent prognostic factor in prediction of } \\
\text { DFS, DSS, and OS }\end{array}$ \\
\hline & & & 602 & $\begin{array}{l}\text { IHC for CD8 plus CD45RO either in } \\
\text { CT or in IM }\end{array}$ & $\begin{array}{l}\text { 1. Patients with high densities of } \mathrm{CD}^{+} \text {and/or } \mathrm{CD} 45 \mathrm{RO}^{+} \text {cells in } \\
\text { their tumors have significantly prolonged DFS and OS. }\end{array}$ & \\
\hline \multirow[t]{2}{*}{ Galon et al. (17) } & $\mathrm{CRC}$ & I-IV & 75 & $\begin{array}{l}\text { Microarray analysis for genes } \\
\text { encoding T-bet, IRF-1, IFN- } \gamma, \mathrm{CD} 3 \varepsilon \text {, } \\
\mathrm{CD} 8 \text {, granulysin, and GZMB }\end{array}$ & $\begin{array}{l}\text { 1. High expressions of genes encoding genes encoding T-bet, } \\
\text { IRF- } 1 \text {, IFN- } \gamma, \text { CD3e, CD8, granulysin, and GZMB inversely } \\
\text { correlates with tumor recurrence. }\end{array}$ & $\begin{array}{l}\text { Immunoscore: A prognostic factor in prediction } \\
\text { of DFS and OS independent of the } \\
\text { parameters }{ }^{\mathrm{C}}\end{array}$ \\
\hline & & & 415 & $\begin{array}{l}\text { IHC for CD3, CD8 plus CD45RO } \\
\text { either in CT or in IM }\end{array}$ & $\begin{array}{l}\text { 1. Patients with high densities of } \mathrm{CD}^{+}, \mathrm{CD}^{+} \text {or } \mathrm{CD} 45 \mathrm{RO}^{+} \\
\text {memory T cells in their tumors have significantly prolonged DFS } \\
\text { and OS. }\end{array}$ & \\
\hline \multirow[t]{3}{*}{ Pagès et al. (16) } & $\mathrm{CRC}$ & I-IV & 75 & $\begin{array}{l}\text { PCR for mRNA encoding CD8, T-bet, } \\
\text { IRF-1, IFN- } \gamma \text {, granulysin and GZMB }\end{array}$ & $\begin{array}{l}\text { 1. Tumors without VELIPI show higher levels of mRNA encoding } \\
\text { mRNA encoding CD8, T-bet, IRF-1, IFN- } \gamma \text {, granulysin and } \\
\text { GZMB than those with VELIPI. }\end{array}$ & $\begin{array}{l}\text { Patients with high density of } \mathrm{CD} 45 \mathrm{RO}^{+} \text {cells in } \\
\text { their tumors have improved DFS and OS than } \\
\text { those with low density of CD45RO+ cells }\end{array}$ \\
\hline & & & 39 & $\begin{array}{l}\text { Flow-cytometry for } \mathrm{CD} 8^{+} \mathrm{CD} 45 \mathrm{RO}^{+} \mathrm{T} \\
\text { cells in tumor }\end{array}$ & $\begin{array}{l}\text { 1. Tumors without VELIPI show higher amount of } \\
\mathrm{CD} 8^{+} \mathrm{CD} 45 \mathrm{RO} \mathrm{O}^{+} \mathrm{T} \text { cells than those with VELIPI. }\end{array}$ & \\
\hline & & & 415 & $\mathrm{IHC}$ for $\mathrm{CD} 45 \mathrm{RO}$ in tumor & $\begin{array}{l}\text { 1. High density of CD45RO } \mathrm{R}^{+} \text {cells in tumor correlates with } \\
\text { absence of VELIPI and early TNM-stage. }\end{array}$ & \\
\hline $\begin{array}{l}\text { Van den Eynde } \\
\text { et al. (12) }\end{array}$ & $\mathrm{mCRC}$ & IV & 603 & $\begin{array}{l}\text { IHC for CD3, CD8, CD45RO, FOXP3, } \\
\text { CD20 and PD-L1 in tumor }\end{array}$ & $\begin{array}{l}\text { 1. Patients receiving preoperative systemic therapies present their } \\
\text { metastases rather than primary tumors with higher densities of } \\
\mathrm{CD}^{+}, \mathrm{CD} 8^{+} \text {, and } \mathrm{CD} 45 \mathrm{RO} \mathrm{O}^{+} \text {cells in IM than those without } \\
\text { treatment. } \\
\text { 2. Preoperative chemotherapy plus anti-EGFR is apt to increase } \\
\text { the densities of } \mathrm{CD} 8^{+} \text {cell and } \mathrm{PD}-1^{+} \text {cell in IM and } \mathrm{CT} \text { of } \\
\text { metastases, and FOXP3 }{ }^{+} \text {cell density in primary tumors. } \\
\text { 3. Preoperative chemotherapy plus anti-VEGF therapies is apt to } \\
\text { increase } \mathrm{B} \text { cell density in primary tumors. } \\
\text { 4. The metastases in a CRC patient differ in their Immunoscore. } \\
\text { 5. The metastatic lesion bearing least amounts of immune } \\
\text { infiltrates (CD3/CD8/CD2O) has the highest risk of relapse in a } \\
\text { mCRC patient. } \\
\text { 6. Immunoscore is superior to PD-L1 in reflecting the immune } \\
\text { infiltrates of metastases. }\end{array}$ & $\begin{array}{l}\text { The DFS of a mCRC patient is highly } \\
\text { associated with the metastases with least } \\
\text { Immunoscore (CD3 plus CD8) or least T-B } \\
\text { score (CD8 plus CD20) }\end{array}$ \\
\hline
\end{tabular}




Author (Ref) Cancer $\begin{array}{cccc}\text { TNM- } & \text { Sample } & \text { Method Main results } & \text { Multivariant analysis for the independence }\end{array}$

\begin{tabular}{lllcl}
\hline Author & $\begin{array}{c}\text { Cancer) } \\
\text { location }\end{array}$ & $\begin{array}{c}\text { TNM- } \\
\text { stage }\end{array}$ & $\begin{array}{c}\text { Sample } \\
\text { size }\end{array}$ & Method \\
\hline Wang et al. (20) & CRCLM & IV & 249 & IHC for CD3 plus CD8 in IM and CT \\
Mlecnik et al. (21) & mCRC & IV & 441 & $\begin{array}{l}\text { IHC for CD3, CD8, CD45RO, CD20 } \\
\text { and FOXP3 in IM and CT }\end{array}$
\end{tabular}

1. CRCLM patients with high Immunoscore in their metastatic

Mlecnik et al. (22) CRC I-III $760 \quad$ Integrative analysis for gene expression

IHC for CD8 and CD45 RO in IM and CT

Mlecnik et al. (23) CRC I-IV $314 \quad$ Genomic profiling

$524 \quad \mathrm{HC}$ for $\mathrm{CD} 3, \mathrm{CD} 8, \mathrm{CD} 57$, T-bet, CD45RO, CD68, CD1A, GZMB, and PDPN in IM and CT interferon signaling pathway, antigen processing and tumors have significant improvement in RFS and OS comparing to those with low Immunoscores after liver surgery.

1. The metastatic lesion with the lowest Immunoscore (CD3 plus CD8) or T-B score (CD8 plus CD20) determines the DFS and OS of a $\mathrm{mCRC}$ patient.

2. Except for $\mathrm{CD} 45 \mathrm{RO}$ and FoxP3, the densities of $\mathrm{CD}^{+}, \mathrm{CD}^{+}$ and $\mathrm{CD}_{2} \mathrm{O}^{+}$in IM and CT are significantly higher in TRG 1-3 tumors than in TRG 4-5 tumors after preoperative treatment.

Immunoscore

Immunoscore: A prognostic factor in prediction of RFS and OS $\$$ independent of the parameters ${ }^{\mathrm{D}}$

Both Immunoscore and T-B score are

prognostic factors in prediction of DFS and OS independent of the parameters ${ }^{E}$

1. MSI tumors commonly have higher expressions of genes encoding IFN- $\gamma$, IL-15, GNLY, CCL3, CCL16, and markers indicating cytotoxicity, CD8, Th1, Th2, and Tfh

Immunoscore: A prognostic factor in prediction of DSS\#, DFS\#, and OS\& independent of the parameter ${ }^{F}$

2. MSI tumors commonly have higher densities of cytotoxic $T$ cell, $\mathrm{B}$ cell, and macrophage in IM and CT than MSS tumors.

3. MSI tumors commonly possess high frequency of frameshift mutations, immunoediting, and functional specific anti-tumoral T cells.

1. MSI tumors have high frequency of high Immunoscore than MSS tumors.

2. A subpopulation of MSS tumors can have high Immunoscore.

1. M1 tumors show higher frequency of $V H L$ and FBXW7 deletions than $\mathrm{MO}$ tumors.

2. M1 tumors significantly downregulate their expressions of genes participating in T cell activation, costimulation, proliferation, IFN- $\gamma$ secretion, response to IFN- $\gamma$, type presentation via MHC-I/II.

1. M1 tumors commonly have lower PDPN ${ }^{+}$lymphatic vessel density than $\mathrm{MO}$ tumors.

2. $\mathrm{M} 1$ tumors commonly have lower densities of $\mathrm{CD}^{+}, \mathrm{CD}^{+}$,

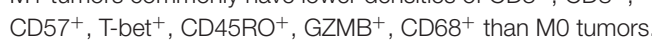

Either Immunoscore (CD3 plus CD8) or GZMB plus PDPN score discriminate OS of CRC patients with or without metastasis

A Patient age, sex, T-stage, N-stage, MSI/MSS, mucinous colloid type, VELIPI, poor differentiation.

${ }^{B}$ Patient sex, T-stage, $N$-stage, total number of lymph nodes, histologic grade, mucinous colloid type, occlusion, bowel perforation

${ }^{C}$ T-stage, $N$-stage, histological grade/differentiation.

D Patient age, sex, primary tumor location, T-stage, interval from primary tumor resection to liver metastases, perioperative chemotherapy $\$$, number of metastases $\$ \$ \$$ showing independence in prediction of OS).

EPatient age, T-stage, N-stage, primary tumor location, preoperative treatment (Chemotherapy or plus anti-angiogenic therapy or anti-EGFR therapy), histological grade/differentiation, metastasis surgery R status (RO or R1), number of metastases, synchronous, or metachronous metastasis, TRG, RAS status, and two-stage hepatectomy.

${ }_{F}$ Patient sex, T-stage, N-stage, histological grade, VELIPI", Mucinous colloid type, tumor occlusion, tumor perforation and MSI status (\#showing independence in prediction of DSS and DFS; \& showing independence in prediction of OS).

CRCLM, colorectal cancer liver metastasis; CT, center region of tumor; mCRC, metastatic colorectal cancer; DFS, disease-free survival; DSS, disease-specific survival; RFS, relapse-free survival; OS, overall survival; IHC, immunohistochemical staining technology; IM, invasive margin of tumor; PCR, polymerase chain reaction technology; TRG, tumor remission grade; VELIPI, venous emboli and lymphatic and perineural invasion. 
phenotype $(10,11)$, and MSI testing has been recommended for selecting CRC patients who can benefit from immune checkpoint blockade (2). Concerning the prognostic value of MSI in CRC, a study reported that among all molecular subgroups of CRC, patients with MSI phenotypes can have their prognoses at a moderate level (6), however, their prognoses will get worst after tumor relapse (6). Moreover, when comparing the abilities of the Immunoscore and an MSI phenotype in predicting the prognosis of CRC patients, significant discrepancies still exist in predicting the prognosis of CRC patients; that is, the MSI phenotype suggests that patients with low scores (0-2 points) still exhibit shorter DFS and OS than those with high scores (3-4 points) (22). In this regard, Immunoscore exhibits the superiority to MSI phenotype in predicting CRC prognoses. In addition, patients with microsatellite stability (MSS) or an MSI phenotype also present comparable DFS and OS values when they share similar Immunoscores in their tumors, thus confirming that the prognosis of CRC patients depends on the Immunoscore rather than on MSI or MSS status (22). Actually, the Immunoscore exhibits value in predicting CRC prognosis regardless of several other factors, such as patient sex, tumor-associated occlusion or perforation, TNM stage, histologic grade, mucinous colloid type, vascular emboli of tumor cells, lymphatic invasion, perineural invasion, and the genomic alteration pattern of CRC cells (15, $22,23)$. Thus, these data confirm that the Immunoscore is able to independently determine the prognosis of CRC patients.

\section{IMMUNOSCORE: APPLICATIONS IN THE CLINICAL SETTING}

Evaluating tumoral Immunoscores indeed provides novel insights into the prediction of CRC prognosis. What are the latent applications of this system in clinical settings? The TNM staging system for comparing CRC severity mainly relies on indexes, including tumor invasion depth, number of involved regional lymph nodes, and the type of distant organs involved. However, it is common to observe that CRC patients differ in their prognoses even if they have the same disease stage. Referring to the relationship between Immunoscore and TNM stage, it has been revealed that the Immunoscore generally decreases as the TNM stage increases (26). However, Immunoscores are heterogenous even in CRC tumors of the same TNM stage (26). Moreover, albeit at a low incidence, a certain portion of cases at advanced stages still possess high Immunoscores in their tumors, favoring prolonged patient survival (26). In this regard, introducing Immunoscores into the TNM staging system should enable the prediction of CRC prognosis to be more informed. In particular, if patients at early stages have rapid disease progression, the Immunoscore will assist in this context. As documented, about $20-25 \%$ of CRC patients at early stages can have relapse in their disease after surgery, indicating the surgery alone is not sufficient for treating their disease (9). Herein, it has been reported that early-staged CRC patients with tumoral Immunoscore at 0-2 points exhibit high risks of disease relapse (18). Thus, adjuvant therapies are encouraged to be included to improve their prognosis (9). In fact, this situation is more applicable for patients at stage II (27), because the most heterogeneous Immunoscores are present at this stage (15). Nowadays, duplet chemotherapy has been used as an adjuvant therapy for highrisk stage II colon cancers, which are characterized by the presence of at least one of the criteria including pT4 tumor; G3; bowel obstruction or perforation; vascular, lymphatic, or perineural invasion on histologic specimens; and fewer than 12 nodes examined. Apart from these risk factors, we propose the Immunoscore should be taken into account to enable the treatment decision more precisely and personally, especially for those early cases without aforementioned risk factors but only with low Immunoscores in their tumors. Nevertheless, to determine the value of Immunoscores in combining adjuvant therapies or not in early-staged CRC, extensive work should be done in the future.

In addition to adding value to the TNM staging system, the tumoral Immunoscore can be boosted by using conventional treatment strategies. For example, neoadjuvant chemoradiotherapy (nCRT) is strongly recommended as a downstaging therapy for local advanced rectal cancer (LARC) (3). Herein, some retrospective studies have revealed that nCRT is able to increase the tumoral densities of $\mathrm{CD} 8^{+} \mathrm{T}$ cells among some LARC tumors (28-30). Tumor control after nCRT is mostly due to direct cytotoxic effects, $\mathrm{T}$ cell infiltration might be a by-product. Thus, it is reasonable to speculate that nCRT potentially improves the immune milieu of a CRC tumor because of the increased tumoral infiltration of $\mathrm{CD}^{+} \mathrm{T}$ cells. On this basis, a phase 2 trial was designed to investigate the downstaging efficacy of nCRT followed by immunotherapy in LARC, and the preliminary results report that $\sim 30 \%$ of enrolled patients have achieved pathological complete remission (pCR) after receiving five cycles of nivolumab post-nCRT (31). Hopefully, such a strategy will cause significant clinical complete remissions (cCRs) among a portion of LARC patients. cCR certainly benefits those patients who are willing to undergo the "watch and wait" strategy rather than immediate surgery, because pooled analysis results reveal that the LARC patients with cCRs post-nCRT have a 5 -year survival rate of $100 \%$ (32). Tumors in the rectum have a low incidence of MSI phenotype (33), and thus, monitoring the Immunoscore before and after nCRT will be helpful in the selection of patients who can potentially benefit from immune checkpoint inhibitors. At least, a study had revealed that CRC tumors with high Immunoscore have a significant overrepresentation of the frequency of cells expressing PD-1 in CT and IM, as well as increased expression of $P D-1$ mRNA (22). More strikingly, this study also found that about 50\% of MSS tumors could have a high Immunoscore (22). In this regard, Immunoscore can become an available biomarker in selecting the candidates benefiting from immune-checkpoint inhibitors.

\section{IMMUNOSCORE IN GUIDING IMMUNOTHERAPY: ADVANTAGES AND PITFALLS}

Currently, the available biomarkers for immunotherapy success include PD-L1 expression by tumor cells, tumor mutational 
burden, and deficient mismatch repair (dMMR) and MSI phenotypes (34). In current clinical trials, CRC patients with dMMR or MSI phenotypes are mostly encouraged to receive immunotherapy. Yet, the data from phase 3 trials indicate that not all of these patients will acquire full benefit from immune-checkpoint inhibitors (10, 11), thus revealing a pitfall of using MSI or dMMR in the selection of immunotherapy candidates. Nevertheless, it has been proposed that the Immunoscore will provide perspectives in guiding the application of immunotherapy (9). Technically, similar to other biomarkers, the Immunoscore evaluation is easy to perform and involves immunohistochemistry staining (9). Moreover, retrospective data have confirmed that Immunoscores have higher accuracy than MSI status (22) and PD-L1 (12) in reflecting the immune status of CRC tumors. However, the Immunoscore system still exhibits drawbacks, because it contains no information concerning the survival, function, and metabolic processes of $\mathrm{T}$ cells or their interactions with surrounding substances in tumors (27). For example, IL-15 deficiency has been reported to impair the proliferation and survival of T cells in CRC tumors, potentially limiting an increase in Immunoscore (35). Currently, trials evaluating the accuracy of the Immunoscores in selecting immunotherapy candidates in CRC are lacking. Therefore, it is difficult to determine the shortcomings of this system in guiding the application of immunotherapy in CRC.

\section{IMMUNE INFILTRATE: CUEING THE IMMUNE LANDSCAPE OF CRC}

In comparison with the Immunoscore, immune landscape profiling appears to be more promising, because it has been accepted that CRC-associated immune infiltrates can vary their phenotypes in a spatiotemporal manner $(12,13)$. Especially in metastatic cases, not only should the most prominent type of immune infiltrates be identified synchronously in primary and metastatic sites (12) but also the main biological processes at play in these cells should be targeted in a given period (36). For example, it has been demonstrated that in metastatic CRC, the tumor bearing the fewest tumoricidal immune infiltrates exhibits the highest risk of relapse (12). In this regard, it is reasonable to speculate that the responses to immunotherapy among metastatic tumors will vary. In the following sections, the potential impacts of several critical infiltrates on the effectiveness of immunotherapy and CRC prognosis will be discussed (Figure 1 and Table 2).

\section{Cytotoxic T Cells}

$\mathrm{CD}^{+} \mathrm{T}$ cells are the most potent cytolytic cell subset. Cytotoxic processes are carried out by several substances produced by $\mathrm{CD}^{+} \mathrm{T}$ cells, such as GZMB, perforin, Fas ligand (FasL), and TNF- $\alpha$ (37). Like CD8 ${ }^{+} \mathrm{T}$ cells, cytotoxic $\mathrm{CD} 4^{+} \mathrm{T}$ cells affect cell death via the Fas/FasL and GZMB/perforin pathways (37). In contrast to other $\mathrm{CD}^{+}{ }^{+} \mathrm{T}$ subsets, cytotoxic $\mathrm{CD} 4^{+} \mathrm{T}$ cells have developmental programs of their own (68). In response to tumoral antigens, cytotoxic $\mathrm{CD}^{+} \mathrm{T}$ cells will increase in numbers (69). Moreover, a recent study confirmed that CRC patients with a favorable prognosis commonly have tumor immune cell infiltrates with increased cytolytic activities (38). However, the number of cytotoxic T cells decreases as TNM-stage increases in CRC (19).

In humans, $\mathrm{CD}^{+}$cytotoxic $\mathrm{T}$ cells $(39), \mathrm{CD}^{+}$cytotoxic T cells (69), and Th1 cells (69) are the most critical subsets producing IFN- $\gamma$. This cytokine functions by exclusively stimulating the JAK1/2-STAT1 pathway, which provokes several immunological processes, including macrophage activation, MHC-I/II pathway upregulation, costimulation, Treg cell inhibition, and Th1 cell differentiation and activation $(39,40)$. All these processes belong to the IFN- $\gamma$-mediated type- 1 immune response, which profoundly elicits tumor remission. In parallel with cytotoxic T cells, a high density of tumoral Th1 cells predicts a favorable prognosis in CRC (70). Meanwhile, tumoral infiltrations of cytotoxic T cells and Th1 cells and IFN- $\gamma$ upregulation serve as hallmarks indicating a good response to immune checkpoint inhibitors (71), because IFN- $\gamma$ can upregulate PD-L1 and MHC-I expression by tumor cells (72). However, any deficiency leading to JAK1/2-STAT1 activation will distort the therapeutic efficacies of immune checkpoint inhibitors (73). This suggests that IFN- $\gamma$ can synergize with the effectiveness of immune checkpoint inhibitors.

\section{Treg Cells}

In humans, Treg cells are the most critical source of IL10. This cytokine can exert multiple effects on immune cells, such as reducing the cytotoxic activity of $\mathrm{CD}^{+} \mathrm{T}$ cells, downregulating MHC-II-restricted antigens or CD80/CD86 expression by monocytes, inhibiting the synthesis of IFN- $\gamma$ or TNF- $\alpha$, and blocking the effector functions of dendritic cells and other $\mathrm{CD}^{+} \mathrm{T}$ cell subsets (Th1, Th2, or Th17 cells) $(74,75)$. In addition, IL-10 can upregulate the expression of CTLA- 4 by Treg cells and strengthen their immunosuppressive potencies (48). However, results from several retrospective studies still support that tumoral infiltration of Treg cells potentially prolongs the survival of CRC patients (41-45). Experimentally, it has been confirmed that IL-10 is required for host immune surveillance and restricts carcinogenesis in the small intestine of mice (76). Strikingly, Treg cell densities in CRC specimens were found to inversely correlate with tumoral PD-L1 expression levels (77). In theory, reduced expression of PD-L1 will assist in protecting against $\mathrm{T}$ cell exhaustion. In fact, Treg cells are prone to apoptosis in CRC tumors (47). Functionally, apoptotic Treg cells are more efficient than live cells in downregulating the expression of IFN- $\gamma$, TNF- $\alpha$, and IL- 2 by tumoricidal T cells (47), while the pre-existence of apoptotic Treg cells in CRC tumors potentially distorts the therapeutic efficacies of immune checkpoint inhibitors (47). In this regard, apoptotic Treg cells impact more in the response of CRC to immune checkpoint inhibitors than living ones.

In contrast, other studies have found that tumoral Treg infiltration fails to predict the prognosis of CRC $(46,78)$. However, increased densities of Treg cells are associated with poor tumor differentiation and increased lymph node involvement (46). In fact, Treg cells contain heterogeneous subsets, and some of them contribute to CRC progression, such 


\section{CD4 or CD8 cytotoxic T and Th1}

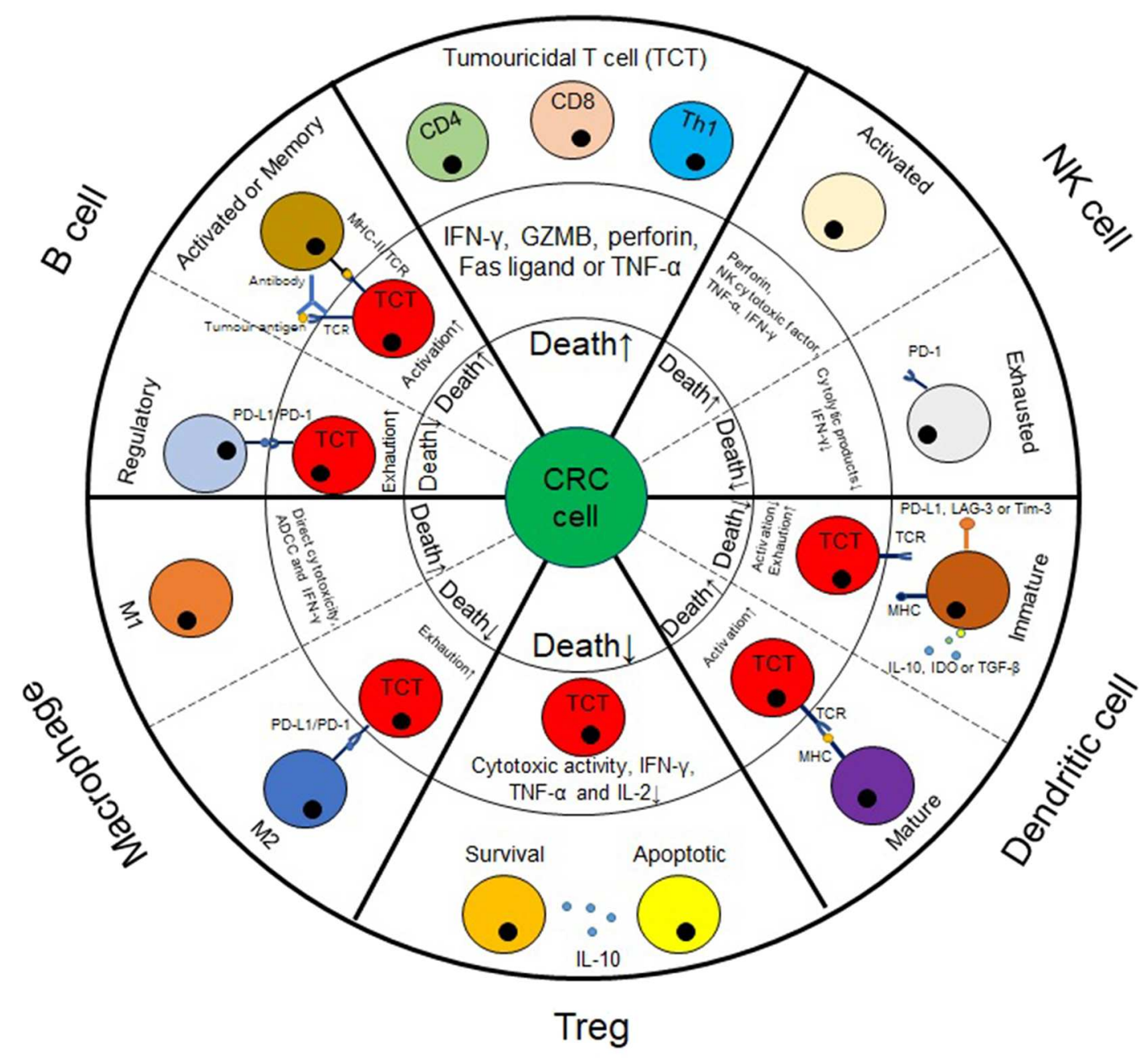

FIGURE 1 | The impact of immune infiltrates on colorectal cancer cell death. In CRC tumors, immune infiltrates can impact CRC cell death, either directly or via tumoricidal T cells (TCT) and consequently affect tumor progression. For example, cytotoxic T cells, M1-like macrophages and NK cells can exert cytolytic effect on CRC cells. For other populations of cells, such as Treg, B cells, dendritic cells or M2-like macrophages, they generally impact CRC cell death by mediating the tumoricidal activity of TCT cells. Herein, Treg, regulatory B cells, immature dendritic cells and M2-like macrophages enable TCT cells to be exhausted, thus causing substantial progression in CRC tumors. By contrast, mature dendritic cells, activated or memory B cells generally induce TCT cell activation, thus causing tumor cell death.

as $\mathrm{CD}^{+}$Treg cells (79), ROR $\gamma \mathrm{t}^{+}$Treg cells (80) and IL-17producing Treg cells (81). Typically, ROR $\gamma t$ is pivotal in Th17 cell polarization (82). The expression of ROR $\gamma \mathrm{t}$ and IL-17 reflects the plasticity of Treg cells, especially in the presence of TGF- $\beta$, IL1 , IL-6, and IL-23 $(58,83,84)$. As such, the density of Treg cells along with their associated cytokine profiles in tumors should be determined jointly, thus enabling an increase in the use of Treg cells in predicting CRC prognosis.

\section{B Cells}

B cells include heterogeneous subsets and dominate antibody production, antigen presentation, and immunosuppression (85). In the healthy gut, $\mathrm{B}$ cells are widely distributed in the lamina propria and isolated lymphoid follicles (86). Like T cells, B cells require IL-15 to maintain their proliferation and survival (35). In the gut, they participate in epithelial barrier maintenance by producing secretory IgA (sIgA) while assisting in secretory IgM (sIgM) production by gut plasma cells (87). sIgA and sIgM are critical antibodies in protection against intestinal bacterial dysbiosis, which serves as an intrinsic factor in the induction of gut carcinogenesis (88).

When CRC occurs, the B cell subsets in peripheral blood, mesenteric lymph nodes and primary tumors differ in their phenotype indicating “activation" (89). Tumoral B cells form islet-like structures (90), which are induced predominantly by follicular helper $\mathrm{T}$ cells (10). In general, tumoral B cells 
TABLE 2 | Immune infiltrate-dedicated tumoral microenvironment and CRC immunotherapy.

\begin{tabular}{|c|c|c|c|c|c|}
\hline Infiltrate & $\begin{array}{l}\text { TNM } \\
\text { stage } \uparrow\end{array}$ & Immunopotent & Immunosuppression & Immunotherapy & Main effects \\
\hline \multirow[t]{3}{*}{ Cytotoxic T cell } & $\downarrow(9,19)$ & $\sqrt{ }$ & NM & ${ }^{1}$ Pros in anti-PD-(L)1 & Cytotoxicity: Perforin, Fas ligand, TNF- $\alpha$, GZMA/GZMB (37) \\
\hline & & & & & Favorable prognosis: Cytolytic activity $\uparrow \rightarrow$ Favorable prognosis (38) \\
\hline & & & & & ${ }^{1}$ Critical responder to immune-checkpoint inhibitors \\
\hline \multirow[t]{3}{*}{ Th1 cell } & $\downarrow(9,19)$ & $\sqrt{ }$ & NM & ${ }^{2}$ Pros in anti-PD-(L)1 & Tumoricidal function: IFN- $\gamma$-mediated type- 1 immune response $(39,40)$ \\
\hline & & & & & $\begin{array}{l}\text { Favorable prognosis: Tumoral Th1 density and IFN }-\gamma \uparrow \rightarrow \text { Favorable } \\
\text { provnosis }(9,19)\end{array}$ \\
\hline & & & & & ${ }^{2}$ Critical responder to immune-checkpoint inhibitors \\
\hline \multirow[t]{4}{*}{ Treg cell } & NM & $\sqrt{ }($ Advantage $)$ & $\sqrt{ }($ Pitfall) & ${ }^{3}$ Pros in anti-CTLA4 & Advantage: Tumoral density of Treg $\uparrow$ Patient survival $\uparrow(41-45)$ \\
\hline & & & & & $\begin{array}{l}\text { Pitfall: Tumoral density of Treg } \uparrow \rightarrow \text { Poor tumor differentiation and more } \\
\text { lymph node involvement (46) }\end{array}$ \\
\hline & & & & & $\begin{array}{l}\text { Apoptotic Treg cells are efficient in downregulating IFN- } \gamma, \mathrm{TNF}-\alpha \text {, and } \\
\text { IL-2 by tumoricidal T cells (47). }\end{array}$ \\
\hline & & & & & ${ }^{3}$ IL-10 induces CTLA-4 upregulation in Treg cells (48) \\
\hline \multirow[t]{3}{*}{ B cell } & NM & $\sqrt{ }($ Advantage $)$ & $\sqrt{ }($ Pitfall) & ${ }^{4}$ Pros in anti-PD-(L)1 & $\begin{array}{l}\text { Advantage: Tumoral densities of cytotoxic T and B cells } \uparrow \rightarrow \text { Patient } \\
\text { survival } \uparrow(12,21)\end{array}$ \\
\hline & & & & & Pitfall: ${ }^{4}$ PD-L1 by Breg cells elicits T cell exhaustion (49) \\
\hline & & & & & IL-35-producing B cells recruit MDSCs (50) \\
\hline \multirow[t]{2}{*}{ Natural killer cell } & $\downarrow$ & $\sqrt{ }$ & NM & ${ }^{5}$ Pros in anti-PD-(L)1 & Tumoricidal function: Cytotoxicity and IFN- $\gamma$ production (51) \\
\hline & & & & & $\begin{array}{l}{ }^{5} \text { But NK cells are prone to exhaustion upon gut carcinogenesis } \\
\text { with a phenotype of upregulation of PD-1 (51) }\end{array}$ \\
\hline \multirow[t]{4}{*}{ Dendritic cell } & $\downarrow(52)$ & $\sqrt{ }($ Advantage $)$ & $\sqrt{ }($ Pitfall) & ${ }^{6}$ Pros in anti-PD-(L)1 & $\begin{array}{l}\text { Advantage: } \mathrm{CD} 103^{+} \text {myeloid DCs } \rightarrow \mathrm{CD}^{+} \text {or } \mathrm{CD}^{+} \mathrm{T}^{-} \text {cell } \\
\text { activation }(53)\end{array}$ \\
\hline & & & & & Pitfall: Plasmacytoid DCs $\rightarrow$ Treg cell induction (54) \\
\hline & & & & & $\begin{array}{l}\text { VEGF, PGE2, TGF- } \beta \text {, IL-10, IDO } \rightarrow \text { DC maturation } \downarrow, \text { MHC-II and } \\
\text { co-stimulatory molecules } \downarrow \rightarrow \text { poor T cell activation }(53-55)\end{array}$ \\
\hline & & & & & $\begin{array}{l}{ }^{6} \text { Immature DCs induce T cell exhaustion by PD-L1, Tim3, LAG3, } \\
\text { IDO, IL-10 and TGF- } \beta(53-55)\end{array}$ \\
\hline \multirow[t]{3}{*}{$\begin{array}{l}\text { Tumor-associated } \\
\text { macrophage (TAM) }\end{array}$} & NM & $\sqrt{ }($ Advantage $)$ & $\sqrt{ }($ Pitfall) & ${ }^{7}$ Pros in anti-PD-(L)1 & $\begin{array}{l}\text { Advantage: Density of CD68 }{ }^{+} \text {M1-like TAMs in primary tumor } \uparrow \rightarrow \\
\text { Patient survival } \uparrow(56-58)\end{array}$ \\
\hline & & & & & $\begin{array}{l}\text { Pitfall: M2-like TAMs promote metastatic tumor progression by } \\
\text { producing IL-35, IL-10, TGF- } \beta \text {, VEGF, and CCL2 (59-66) }\end{array}$ \\
\hline & & & & & $\begin{array}{l}{ }^{7} \text { M2-like TAMs attract CD4 }{ }^{+} \text {or } \mathrm{CD}^{+} \mathbf{T} \text { cells to cluster around } \\
\text { them (67), thus eliciting T cell exhaustion by using PD-L1 (65) }\end{array}$ \\
\hline
\end{tabular}

NM, not mentioned.

are commonly activated and have memory phenotypes (91). They can activate tumoricidal $\mathrm{T}$ cells to manipulate cancer cell death due to their effectiveness in antigen presentation and costimulation. However, a recent study has revealed that a high density of tumoral B cells predicts favorable clinical outcome only in patients with right-sided colon cancer, rather than left-sided colon cancer or rectal cancer (90). Evaluating the densities of tumoricidal T cells, Treg cells, and B cells together might improve the accuracy of CRC prognosis prediction (12).

Not all B cells assist in the tumoricidal process. Upregulation of CXCL9 and CXCL10 in CRC tumors can attract regulatory B (Breg) cells as well, although such chemoattractants are also potent in recruiting tumoricidal T cells (49). Breg cells express $\mathrm{PD}-\mathrm{L} 1$, thus severing as a route inducing $\mathrm{T}$ cell exhaustion (49). In addition, IL-35-producing B cells have been observed to increase their numbers upon CRC progression (50). This context will attract more myeloid-derived suppressive cells (MDSCs) (50).

\section{Natural Killer Cells}

Natural killer (NK) cells also exert cytolytic function. At steady state, NK cells stand in the frontline against gut carcinogenesis (92). If CRC occurs, NK exhaustion will occur, resulting in a reduction in cytotoxic activity, IFN- $\gamma$ downregulation, and PD1 upregulation (92). Inherently, CRC cells can heterogeneously express NKG2D ligands, such as MICA and ULBP2/3, whereas MICB is always absent (93). As stress proteins, MICA, and MICB are crucial in mediating the activation of the recognition pathway in cytotoxic lymphocytes, whereas proteolytic shedding of these proteins leads to tumor evasion (94). Alternatively, if CRC cells are deficient in MHC-I expression or function, NK cells will limit their expansion and reduce the production of IFN $-\gamma, \mathrm{GZMB}$, and perforin (51).

In parallel with cytotoxic $\mathrm{T}$ cells, NK cells have reduced numbers in tumors as TNM-stage increases (92). In metastatic CRC, it has been found that the number of tumoral NK cells is significantly less than that in peritumoral or normal tissue (95). 
On this basis, the role of tumoral NK cells in CRC prognosis has not been specified (95). However, it is at least known that NK cell infiltration into CRC tumors at advanced disease stages is difficult. To overcome this, quantitation of IFN- $\gamma$ secretion by blood NK cells has been used to identify the cytotoxic status of NK cells, which provides a potential for screening patients at high risk of suffering CRC or monitoring disease progression (92). Alternatively, due to PD-1 upregulation in NK cells upon CRC occurring, immune checkpoint inhibitors should assist in preventing NK cell exhaustion.

\section{Dendritic Cells}

Dendritic cells (DCs) are professional antigen-presenting cells in humans. In the steady-state setting, the hallmark functions of DCs include stimulating $\mathrm{T}$ or B cells, antigen presentation, and immunoregulation. Although the characteristics of human gut DCs are not well-understood (96), DCs located within the intestinal mucosa have been found to have the capacity to support homing of T and B cells from the periphery (96).

In humans, DC progenitors follow diverse paths to commit to plasmacytoid DC (pDC) and myeloid DC (also known as conventional DC, cDC) lineages (97). Their contributions on other immune cells are varied. For example, pDCs are prone to inducing Treg cell generation (98). Occasionally, pDCs can support the tumoricidal processes elicited by other immune cells, such as cDCs, T cells, B cells and NK cells (97). Among cDC subsets, $\mathrm{CDC} 1$ cells that are addicted to the transcriptional factor Batf3 for their polarization have been revealed to have the capacity to elicit $\mathrm{CD} 8^{+} \mathrm{T}$ cell-mediated immune responses via antigen cross-presentation (99). Further investigations support that $\mathrm{CD} 103^{+} \mathrm{CDC} 1$ cells are critical in processing tumor antigens to activate $\mathrm{CD}^{+}{ }^{+}$or $\mathrm{CD}^{+}{ }^{+} \mathrm{T}$ cells (100).

However, there is still no evidence indicating the impact of $\mathrm{CD}_{103}{ }^{+} \mathrm{cDC} 1$ cells on CRC prognosis (41). The existing data indicate that tumoral infiltration of DCs is negatively associated with tumor stages, whereas the prognosis of CRC patients is diverse, because accumulations of DC cells with different phenotypes will result in poor DFS or OS (55). Inherently, immature or mature DCs can exert different effects on CRC progression (55). To help cancer cells escape from immune recognition and killing, DC differentiation and maturation can be inhibited by a panel of cytokines, including VEGF, prostaglandinE2 (PGE2), TGF- $\beta$, IL-1 $\beta$, IL-10, IL-13, and indoleamine-2,3dioxygenase (IDO), which can originate from tumor cells or stromal cells $(97,98,100)$. After contact with these cytokines, DCs downregulate MHC-II, and co-stimulatory molecules, thus resulting in poor $\mathrm{T}$ cell activation $(97,98)$. Moreover, immature DCs are proficient in inducing $\mathrm{T}$ cell exhaustion, because they can express PD-L1, Tim3, LAG3, IL-10, IDO, and TGF- $\beta$, thus strengthening immunosuppression in tumors $(97,98,100)$.

\section{Tumor-Associated Macrophages}

Tumor-associated macrophages (TAMs) are critical immune infiltrates in tumors. In general, they can be classified into two pools, namely, M1- and M2-like TAMs (54). In general, M1-like TAMs are inherently dedicated to antagonizing tumor progression, but M2-like TAMs are not [see details in Mantovani et al. (54)].

The phenotypes of TAMs are plastic. Although several studies have revealed that high densities of $\mathrm{CD}^{+} 8^{+}$macrophages in the tumoral IM predict favorable prognosis in patients with colon cancer $(52,53,101)$, this is not the case in metastatic CRC. For example, more M2-like macrophages can be found in liver metastatic tumors than in primary sites (102). It has been revealed that by producing IL-35, liver TAMs can activate the STAT6-GATA3 axis of CRC cells to facilitate their colonization (102). In addition, exosomes from TP53-mutated CRC cells can induce the upregulation of IL-10, TGF- $\beta$, VEGF, and CCL2 by TAMs in a miRNA-1246-dependent manner (56). In addition to the immunosuppression elicited by VEGF, IL-10 (57) and TGF- $\beta$ (58) are required for M2-like TAM polarization.

To a certain extent, M2-like TAM infiltration is associated with an increased incidence of CRC liver metastasis and promotion of disease progression in the liver. On the one hand, TGF- $\beta$-induced epithelial-mesenchymal transition in cancer stem cells serves as a critical route for CRC liver metastatic lesion formation (59). On the other hand, as a downstream molecule of TGF- $\beta$ signaling, SMAD4 deficiency can lead CRC cells to upregulate the production of CCL15, which interacts with CCR1 on myeloid $\mathrm{CD}_{11} \mathrm{~b}^{+} \mathrm{MPO}^{+}$macrophages to recruit them into the liver (60). By producing metalloproteinase-9, CCR $1^{+}$ macrophages assist in CRC invasion (60). Likewise, CCL2 attracts myeloid $\mathrm{CD}_{1} \mathrm{~b}^{+} \mathrm{Gr}^{+}$macrophages to promote angiogenesis of metastatic tumors in the liver $(61,62)$. Therefore, retrospective studies have revealed that both CCL2 upregulation and CCR2 ${ }^{+}$ TAM accumulation in tumors serve as factors indicating poor prognosis in patients with CRC liver metastasis $(62,63)$.

In parallel with CCL2 and CCL15, CCL5 serves as another chemokine that controls CRC progression (54). Functionally, CCL5 can interact with CCR5 on CRC cells to increase their proliferation, invasiveness, and metastasis (64). In this process, tumoral $\mathrm{CD}^{+}$and $\mathrm{CD}^{+} \mathrm{T}$ cells have been revealed to be the exclusive sources of CCL5 (64). In fact, TAMs are responsible for the events that CCL5 exploits, because they can produce CXCL9 and CXCL10 (64), which serve as critical attractants for $\mathrm{T}$ cell infiltration (64). CCL5 upregulation in metastatic tumors is accompanied by the accumulation of $\mathrm{T}$ cells, which cluster around TAMs (64). However, most of the T cells are of an exhausted phenotype (64). Functionally, TAMs can express PD-L1 (65). In addition, CRC liver metastatic lesions contain higher densities of PD-L1 ${ }^{+}$TAMs than primary sites (65). In this context, the concentrations of IFN $-\gamma$ in CRC metastatic tumors are too low to enable the biological effects of this cytokine to be exerted (64). Therefore, the survival and tumoricidal functions of $\mathrm{T}$ cells can be impaired by TAMs. Additionally, CCL5-deficient mice bearing xenografted CRC display increased densities of tumoral CD8 ${ }^{+} \mathrm{T}$ cells (66), suggesting that CCL5 at least impacts $\mathrm{T}$ cell infiltration. In theory, $\mathrm{T}$ cell absence is believed to be a reason why tumor shrinkage is minimally induced by immune checkpoint inhibitors (103). If this is true, the CCL5-CCR5 axis could serve as a route that promotes CRC progression by excluding $\mathrm{T}$ cells. In fact, it has been proposed that CCL5-CCR5 blockade would potentially improve the anti-tumoral efficacies of 
immune checkpoint inhibitors (67). During this process, TAMs appear to be critical targets as well.

\section{CONCLUSION}

The Immunoscore system provides new insights into reliably predicting CRC prognosis, especially as this system has potential for screening immunotherapy candidates. However, as several other tumoral infiltrates impact the efficacies of immune checkpoint inhibitors, much work is needed to determine whether the Immunoscore will become a superior biomarker indicating CRC immunotherapy. Alternatively, Immunoscore plus other diagnostic tools, such as MSI or

\section{REFERENCES}

1. Zeuner A, Todaro M, Stassi G, De Maria R. Colorectal cancer stem cells: from the crypt to the clinic. Cell Stem Cell. (2014) 15:692705. doi: 10.1016/j.stem.2014.11.012

2. Van Cutsem E, Cervantes A, Adam R, Sobrero A, Van Krieken JH, Aderka D, et al. ESMO consensus guidelines for the management of patients with metastatic colorectal cancer. Ann Oncol. (2016) 27:1386422. doi: 10.1093/annonc/mdw235

3. Glynne-Jones R, Wyrwicz L, Tiret E, Brown G, Rödel C, Cervantes A, et al. Rectal cancer: ESMO clinical practice guideline for diagnosis, treatment and follow-up. Ann Oncol. (2017) 28:iv22-iv40. doi: 10.1093/annonc/mdx224

4. Allemani C, Matsuda T, Di Carlo V, Harewood R, Matz M, Nikšić M, et al. Global surveillance of trends in cancer survival 2000-14 (CONCORD-3): analysis of individual records for 37513025 patients diagnosed with one of 18 cancers from 322 population-based registries in 71 countries. Lancet. (2018) 391:1023-75. doi: 10.1016/S0140-6736(17)33326-3

5. Smeby J, Sveen A, Merok MA, Danielsen SA, Eilertsen IA, Guren MG, et al. CMS-dependent prognostic impact of KRAS and BRAFV600E mutations in primary colorectal cancer. Ann Oncol. (2018) 29:122734. doi: 10.1093/annonc/mdy085

6. Guinney J, Dienstmann R, Wang X, de Reyniès A, Schlicker A, Soneson C, et al. The consensus molecular subtypes of colorectal cancer. Nat Med. (2015) 21:1350-6. doi: 10.1038/nm.3967

7. Absenger G, Szkandera J, Pichler M, Stotz M, Arminger F, Weissmueller M, et al. A derived neutrophil to lymphocyte ratio predicts clinical outcome in stage II and III colon cancer patients. Br J Cancer. (2013) 109:395400. doi: 10.1038/bjc.2013.346

8. Ogino S, Nosho K, Irahara N, Meyerhardt JA, Baba Y, Shima K, et al. Lymphocytic reaction to colorectal cancer is associated with longer survival, independent of lymph node count, microsatellite instability, and CpG island methylator phenotype. Clin Cancer Res. (2009) 15:641220. doi: 10.1158/1078-0432.CCR-09-1438

9. Galon J, Pagès F, Marincola FM, Angell HK, Thurin M, Lugli, et al. Cancer classification using the immunoscore: a worldwide task force. J Transl Med. (2012) 10:205. doi: 10.1186/1479-5876-10-205

10. Overman MJ, McDermott R, Leach JL, Lonardi S, Lenz HJ, Morse MA, et al. Nivolumab in patients with metastatic DNA mismatch repair-deficient or microsatellite instability-high colorectal cancer (CheckMate 142): an open-label, multicentre, phase 2 study. Lancet Oncol. (2017) 18:11821191. doi: 10.1016/S1470-2045(17)30422-9

11. Overman MJ, Lonardi S, Wong KYM, Lenz HJ, Gelsomino F, Aglietta M, et al. Durable clinical benefit with nivolumab plus ipilimumab in DNA mismatch repair-deficient/microsatellite instability-high metastatic colorectal cancer. $J$ Clin Oncol. (2018) 36:773-9. doi: 10.1200/JCO.2017.76.9901

12. Van den Eynde M, Mlecnik B, Bindea G, Fredriksen T, Church SE, Lafontaine $\mathrm{L}$, et al. The link between the multiverse of immune microenvironments in metastases and the survival of colorectal cancer patients. Cancer Cell. (2018) 34:1012-26.e3. doi: 10.1016/j.ccell.2018.11.003
dMMR appears to provide better CRC treatment, especially for immunotherapy.

\section{AUTHOR CONTRIBUTIONS}

PC, LG, and CW wrote this paper. XQ and XP prepared the tables of this review. PC conceived this topic of this review, and designed the logic flow.

\section{FUNDING}

This work was supported by grants from the National Natural Science Foundation of China, No. 81874254.

13. Bindea G, Mlecnik B, Tosolini M, Kirilovsky A, Waldner M, Obenauf AC, et al. Spatiotemporal dynamic of intratumoral immune cells reveal the immune landscape in human cancer. Immunity. (2013) 39:78295. doi: 10.1016/j.immuni.2013.10.003

14. Pagès F, Galon J, Dieu-Nosjean MC, Tartour E, Sautès-Fridman C, Fridman WH. Immune infiltration in human tumors: a prognostic factor that should not be ignored. Oncogene. (2010) 29:1093-102. doi: 10.1038/onc.2009.416

15. Pagès F, Mlecnik B, Marliot F, Bindea G, Ou FS, Bifulco C, et al. International validation of the consensus Immunoscore for the classification of colon cancer: a prognostic and accuracy study. Lancet. (2018) 391:212839. doi: 10.1016/S0140-6736(18)30789-X

16. Pagès F, Berger A, Camus $M$, Sanchez-Cabo F, Costes A, Molidor $\mathrm{R}$, et al. Effector memory $\mathrm{T}$ cells, early metastasis, and survival in colorectal cancer. N Engl J Med. (2005) 353:2654-66. doi: 10.1056/NEJMoa0 51424

17. Galon J, Costes A, Sanchez-Cabo F, Kirilovsky A, Mlecnik B, LagorcePagès C, et al. Type, density, and location of immune cells within human colorectal tumors predict clinical outcome. Science. (2006) 313:19604. doi: 10.1126/science.1129139

18. Pagès F, Kirilovsky A, Mlecnik B, Asslaber M, Tosolini M, Bindea $\mathrm{G}$, et al. In situ cytotoxic and memory $\mathrm{T}$ cells predict outcome in patients with early-stage colorectal cancer. J Clin Oncol. (2009) 27:594451. doi: 10.1200/JCO.2008.19.6147

19. Mlecnik B, Tosolini M, Kirilovsky A, Berger A, Bindea G, Meatchi T, et al. Histopathologic-based prognostic factors of colorectal cancers are associated with the state of the local immune reaction. J Clin Oncol. (2011) 29:6108. doi: 10.1200/JCO.2010.30.5425

20. Wang Y, Lin HC, Huang MY, Shao Q, Wang ZQ, Wang FH, et al. The immunoscore system predicts prognosis after liver metastasectomy in colorectal cancer liver metastases. Cancer Immunol Immunother. (2018) 67:435-44. doi: 10.1007/s00262-017-2094-8

21. Mlecnik B, Van den Eynde M, Bindea G, Church SE, Vasaturo A, Fredriksen $\mathrm{T}$, et al. Comprehensive intrametastatic immune quantification and major impact of immunoscore on survival. J Natl Cancer Inst. (2018) 110:97108. doi: 10.1093/jnci/djx123

22. Mlecnik B, Bindea G, Angell HK, Maby P, Angelova M, Tougeron D, et al. Integrative analyses of colorectal cancer show immunoscore is a stronger predictor of patient survival than microsatellite instability. Immunity. (2016) 44:698-711. doi: 10.1016/j.immuni.2016.02.025

23. Mlecnik B, Bindea G, Kirilovsky A, Angell HK, Obenauf AC, Tosolini $\mathrm{M}$, et al. The tumor microenvironment and Immunoscore are critical determinants of dissemination to distant metastasis. Sci Transl Med. (2016) 8:327ra26. doi: 10.1126/scitranslmed.aad6352

24. Kwak Y, Koh J, Kim DW, Kang SB, Kim WH, Lee HS. Immunoscore encompassing $\mathrm{CD}^{+}$and $\mathrm{CD}^{+}{ }^{+} \mathrm{T}$ cell densities in distant metastasis is a robust prognostic maker for advanced colorectal cancer. Oncotarget. (2016) 7:81778-90. doi: 10.18632/oncotarget.13207

25. Dienstmann R, Vermeulen L, Guinney J, Kopetz S, Tejpar S, Tabernero J. Consensus molecular subtypes and the evolution of 
precision medicine in colorectal cancer. Nat Rev Cancer. (2017) 17:79-92. doi: 10.1038/nrc.2016.126

26. Broussard EK, Disis ML. TNM staging in colorectal cancer: $\mathrm{T}$ is for $\mathrm{T}$ cell and $\mathrm{M}$ is for memory. J Clin Oncol. (2011) 29:6013. doi: $10.1200 /$ JCO.2010.32.9078

27. Jorissen RN, Sakthianandeswaren A, Sieber OM. Immunoscore-has it scored for colon cancer precision medicine? Ann Transl Med. (2018) 6:S23. doi: 10.21037/atm.2018.09.29

28. Matsutani S, Shibutani M, Maeda K, Nagahara H, Fukuoka T, Nakao $S$, et al. Significance of tumor-infiltrating lymphocytes before and after neoadjuvant therapy for rectal cancer. Cancer Sci. (2018) 109:96679. doi: $10.1111 /$ cas. 13542

29. Shinto E, Hase K, Hashiguchi Y, Sekizawa A, Ueno H, Shikina A, et al. $\mathrm{CD}^{+}$and $\mathrm{FOXP}^{+}$tumor-infiltrating $\mathrm{T}$ cells before and after chemoradiaotherapy for rectal cancer. Ann Surg Oncol. (2014) 21(Suppl 3):S414-21. doi: 10.1245/s10434-014-3584-y

30. Teng F, Meng X, Kong L, Mu D, Zhu H, Liu S, et al. TILs, FOXP3, PDL1 and CTLA-4 expressions before and after neoadjuvant chemoradiation in rectal cancer. Transl Res. (2015) 166:721-32.e1. doi: 10.1016/j.trsl.2015. 06.019

31. Carducci MA, Giblin J, Dottellis D. 2019 ASCO Annual Meeting Proceedings. J Clin Oncol. (2019) 37:192s.

32. Dossa F, Chesney TR, Acuna SA, Baxter NN. A watch-and-wait approach for locally advanced rectal cancer after a clinical complete response following neoadjuvant chemoradiation: a systematic review and meta-analysis. Lancet Gastroenterol Hepatol. (2017) 2:501-13. doi: 10.1016/S2468-1253(17)30074-2

33. Ma L, Dong L, Chang P. CD44v6 engages in colorectal cancer progression. Cell Death Dis. (2019) 10:30. doi: 10.1038/s41419-018-1265-7

34. Lemery S, Keegan P, Pazdur R. First FDA approval agnostic of cancer site - when a biomarker defines the indication. N Eng J Med. (2017) 377:140912. doi: 10.1056/NEJMp1709968

35. Mlecnik B, Bindea G, Angell HK, Sasso MS, Obenauf AC, Fredriksen T, et al. Functional network pipeline reveals genetic determinants associated with in situ lymphocyte proliferation and survival of cancer patients. Sci Transl Med. (2014) 6:228ra37. doi: 10.1126/scitranslmed.3007240

36. Kather JN, Halama N, Jaeger D. Genomics and emerging biomarkers for immunotherapy of colorectal cancer. Semin Cancer Biol. (2018) 52:18997. doi: 10.1016/j.semcancer.2018.02.010

37. Russell JH, Ley TJ. Lymphocyte-mediated cytotoxicity. Annu Rev Immunol. (2002) 20:323-70. doi: 10.1146/annurev.immunol.20.100201.131730

38. Narayanan S, Kawaguchi T, Yan L, Peng X, Qi Q, Takabe K. Cytolytic activity score to assess anticancer immunity in colorectal cancer. Ann Surg Oncol. (2018) 25:2323-31. doi: 10.1245/s10434-018-6506-6

39. Dunn GP, Koebel CM, Schreiber RD. Interferons, immunity and cancer immunoediting. Nat Rev Immunol. (2006) 6:836-48. doi: 10.1038/nri1961

40. Xu X, Xu J, Wu J, Hu Y, Han Y, Gu Y, et al. Phosphorylation-mediated IFN- $\gamma \mathrm{R} 2$ membrane translocation is required to activate macrophage innate response. Cell. (2018) 175:1336-51. doi: 10.1016/j.cell.2018.09.011

41. Mei Z, Liu Y, Liu C, Cui A, Liang Z, Wang G, et al. Tumour-infiltrating inflammation and prognosis in colorectal cancer: systematic review and meta-analysis. Br J Cancer. (2014) 110:1595-605. doi: 10.1038/bjc.2014.46

42. Berntsson J, Svensson MC, Leandersson K, Nodin B, Micke P, Larsson AH, et al. The clinical impact of tumour-infiltrating lymphocytes in colorectal cancer differs by anatomica subsite: a cohort study. Int J Cancer. (2017) 141:1654-66. doi: 10.1002/ijc.30869

43. Katz SC, Bamboat ZM, Maker AV, Shia J, Pillarisetty VG, Yopp AC, et al. Regulatory $\mathrm{T}$ cell infiltration predicts outcome following resection of colorectal cancer liver metastasis. Ann Surg Oncol. (2013) 20:94655. doi: 10.1245/s10434-012-2668-9

44. Nakagawa K, Tanaka K, Homma Y, Nojiri K, Kumamoto T, Takeda K, et al. Low infiltration of peritumoral regulatory $\mathrm{T}$ cells predicts worse outcome following resection of colorectal liver metastases. Ann Surg Oncol. (2015) 22:180-6. doi: 10.1245/s10434-014-3974-1

45. Salama P, Phillips M, Grieu F, Morris M, Zeps N, Joseph D, et al. Tumorinfiltrating $\mathrm{FOXP}^{+}$regulatory cells show strong prognostic significance in colorectal cancer. J Clin Oncol. (2009) 27:186-92. doi: 10.1200/JCO.2008. 18.7229
46. Zhuo C, Xu Y, Ying M, Li Q, Huang L, Li D, et al. FOXP3 ${ }^{+}$ Tregs: heterogeneous phenotypes and conflicting impacts on survival outcomes in patients with colorectal cancer. Immunol Res. (2015) 61:33847. doi: 10.1007/s12026-014-8616-y

47. Maj T, Wang W, Crespo J, Zhang H, Wang W, Wei S, et al. Oxidative stress controls regulatory $\mathrm{T}$ cell apoptosis and suppressor activity and PD-L1-blockade resistance in tumor. Nat Immunol. (2017) 18:133241. doi: $10.1038 /$ ni.3868

48. Hsu P, Santner-Nanan B, Hu M, Skarratt K, Lee CH, Stormon M, et al. IL10 Potentiates differentiation of human induced regulatory T cell via STAT3 and Foxo1. J Immunol. (2015) 195:3665-74. doi: 10.4049/jimmunol.1402898

49. Liu R, Lu Z, Gu J, Liu J, Huang E, Liu X, et al. MicroRNAs 15A and 16-1 Activate signaling pathways that mediate chemotaxis of immune regulatory B cells to colorectal tumors. Gastroenterology. (2018) 154:63751.e7. doi: 10.1053/j.gastro.2017.09.045

50. Wang K, Gong H, Chai R, Yuan H, Chen Y, Liu J. Aberrant frequency of IL-35 producing B cells in colorectal cancer patients. Cytokine. (2018) 102:206-10. doi: 10.1016/j.cyto.2017.10.011

51. Seo H, Jeon I, Kim BS, Park M, Bae EA, Song B, et al. IL21-mediated reversal of NK cell exhaustion facilitates anti-tumour immunity in MHC class I-deficient tumours. Nat Commun. (2017) 8:15776. doi: $10.1038 /$ ncomms 15776

52. Li S, Xu F, Zhang J, Wang L, Zheng Y, Wu X, et al. Tumorassociated macrophages remodeling EMT and predicting survival in colorectal carcinoma. Oncoimmunology. (2017) 7:e1380765. doi: 10.1080/2162402X.2017.1380765

53. Koelzer VH, Canonica K, Dawson H, Sokol L, KaramitopoulouDiamantis E, Lugli A, et al. Phenotyping of tumor-associated macrophages in colorectal cancer: impact on single cell invasion (tumor budding) and clinicopathological outcome. Oncoimmunology. (2015) 5:e1106677. doi: 10.1080/2162402X.2015.1106677

54. Mantovani A, Marchesi F, Malesci A, Laghi L, Allavena P. Tumour-associated macrophages as treatment targets in oncology. Nat Rev Clin Oncol. (2017) 14:399-416. doi: 10.1038/nrclinonc.2016.217

55. Malietzis G, Lee GH, Jenkins JT, Bernardo D, Moorghen M, Knight $\mathrm{SC}$, et al. Prognostic value of the tumour-infiltrating dendritic cells in colorectal cancer: a systematic review. Cell Commun Adhes. (2015) 22:914. doi: 10.3109/15419061.2015.1036859

56. Cooks T, Pateras IS, Jenkins LM, Patel KM, Robles AI, Morris J, et al. Mutant p53 cancers reprogram macrophages to tumor supporting macrophages via exosomal miR-1246. Nat Commun. (2018) 9:771. doi: 10.1038/s41467-018-03224-w

57. Tagliamonte M, Petrizzo A, Tornesello ML, Buonaguro FM, Buonaguro L. Antigen-specific vaccines for cancer treatment. Hum Vaccin Immunother. (2014) 10:3332-46. doi: 10.4161/21645515.2014.973317

58. Zhou L, Lopes JE, Chong MM, Ivanov II, Min R, Victora GD, et al. TGF- $\beta$-induced Foxp3 inhibits $\mathrm{T}(\mathrm{H}) 17$ cell differentiation by antagonizing RORgammat function. Nature. (2008) 453:236-40. doi: 10.1038/nature06878

59. Chruścik A, Gopalan V, Lam AK. The clinical and biological roles of transforming growth factor beta in colon cancer stem cells: a systematic review. Eur J Cell Biol. (2018) 97:15-22. doi: 10.1016/j.ejcb.2017.11.001

60. Itatani Y, Kawada K, Fujishita T, Kakizaki F, Hirai H, Matsumoto T, et al. Loss of SMAD4 from colorectal cancer cells promotes CCL15 expression to recruit $\mathrm{CCR}^{+}{ }^{+}$myeloid cells and facilitate liver metastasis. Gastroenterology. (2013) 145:1064-75. doi: 10.1053/j.gastro.2013.07.033

61. Zhao L, Lim SY, Gordon-Weeks AN, Tapmeier TT, Im JH, Cao Y, et al. Recruitment of a myeloid cell subset (CD11b/Gr1 mid) via CCL2/CCR2 promotes the development of colorectal cancer liver metastasis. Hepatology. (2013) 57:829-39. doi: 10.1002/hep.26094

62. Lim SY, Gordon-Weeks A, Allen D, Kersemans V, Beech J, Smart S, et al. $\mathrm{Cd}_{11 \mathrm{~b}^{+}}$myeloid cells support hepatic metastasis through downregulation of angiopoietin-like 7 in cancer cells. Hepatology. (2015) 62:5233. doi: $10.1002 /$ hep. 27838

63. Grossman JG, Nywening TM, Belt BA, Panni RZ, Krasnick BA, DeNardo DG, et al. Recruitment of CCR2+ tumor associated macrophage to sites of liver metastasis confers a poor prognosis in human colorectal cancer. Oncoimmunology. (2018) 7:e1470729. doi: 10.1080/2162402X.2018.14 70729 
64. Halama N, Zoernig I, Berthel A, Kahlert C, Klupp F, Suarez-Carmona $\mathrm{M}$, et al. Tumoral Immune cell exploitation in colorectal cancer metastases can be targeted effectively by anti-CCR5 therapy in cancer patients. Cancer Cell. (2016) 29:587-601. doi: 10.1016/j.ccell.2016. 03.005

65. Yomoda T, Sudo T, Kawahara A, Shigaki T, Shimomura S, Tajiri K, et al. The Immunoscore is a superior prognostic tool in stages II and III colorectal cancer and is significantly correlated with programmed death-ligand 1 (PD-L1) expression on tumor-infiltrating mononuclear cells. Ann Surg Oncol. (2019) 26:415-24. doi: 10.1245/s10434-01807110-Z

66. Zhang S, Zhong M, Wang C, Xu Y, Gao WQ, Zhang Y. CCL5deficiency enhances intratumoral infiltration of $\mathrm{CD}^{+} \mathrm{T}$ cells in colorectal cancer. Cell Death Dis. (2018) 9:766. doi: 10.1038/s41419-0180796-2

67. Bronte V, Bria E. Interfering with CCL5/CCR5 at the tumor-stroma interface. Cancer Cell. (2016) 29:437-9. doi: 10.1016/j.ccell.2016.03.019

68. Patil VS, Madrigal A, Schmiedel BJ, Clarke J, O’Rourke P, de Silva $\mathrm{AD}$, et al. Precursors of human $\mathrm{CD}^{+}$cytotoxic $\mathrm{T}$ lymphocytes identified by single-cell transcriptome analysis. Sci Immunol. (2018) 3:eaan8664. doi: 10.1126/sciimmunol.aan8664

69. Mucida D, Husain MM, Muroi S, van Wijk F, Shinnakasu R, Naoe Y, et al. Transcriptional reprogramming of mature $\mathrm{CD} 4^{+}$helper $\mathrm{T}$ cells generates distinct MHC class II-restricted cytotoxic lymphocytes. Nat Immunol. (2013) 14:281-9. doi: 10.1038/ni.2523

70. Zhang Y, Luo Y, Qin SL, Mu YF, Qi Y, Yu MH, et al. The clinical impact of ICOS signal in colorectal cancer patients. Oncoimmunology. (2016) 5:e1141857. doi: 10.1080/2162402X.2016.1141857

71. Masucci GV, Cesano A, Hawtin R, Janetzki S, Zhang J, Kirsch I, et al. Validation of biomarkers to predict response to immunotherapy in cancer: volume I - pre-analytical and analytical validation. J Immunother Cancer. (2016) 4:76. doi: 10.1186/s40425-016-0178-1

72. Zhang J, Dang F, Ren J, Wei W. Biochemical aspects of PD-L1 regulation in cancer immunotherapy. Trends Biochem Sci. (2018) 43:101432. doi: 10.1016/j.tibs.2018.09.004

73. Syn NL, Teng MWL, Mok TSK, Soo RA. De-novo and acquired resistance to immune checkpoint targeting. Lancet Oncol. (2017) 18:e731e41. doi: 10.1016/S1470-2045(17)30607-1

74. Moore KW, de Waal Malefyt R, Coffman RL, O'Garra A. Interleukin10 and the interleukin-10 receptor. Annu Rev Immunol. (2001) 19:683765. doi: 10.1146/annurev.immunol.19.1.683

75. Jones LL, Alli R, Li B, Geiger TL. Differential $\mathrm{T}$ cell cytokine receptivity and not signal quality distinguishes IL-6 and IL10 signaling during Th17 differentiation. J Immunol. (2016) 196:2973-85. doi: 10.4049/jimmunol.1402953

76. Dennis KL, Saadalla A, Blatner NR, Wang S, Venkateswaran V, Gounari F, et al. T-cell expression of IL10 is essential for tumor immune surveillance in the small intestine. Cancer Immunol Res. (2015) 3:80614. doi: 10.1158/2326-6066.CIR-14-0169

77. Masugi Y, Nishihara R, Yang J, Mima K, da Silva A, Shi Y, et al. Tumour CD274 (PD-L1) expression and T cells in colorectal cancer. Gut. (2017) 66:1463-73. doi: 10.1136/gutjnl-2016-311421

78. Sideras K, Galjart B, Vasaturo A, Pedroza-Gonzalez A, Biermann K, Mancham S, et al. Prognositic value of intra-tumoral $\mathrm{CD}^{+} / \mathrm{FoxP}^{+}$ lymphocyte ratio in patients with resected colorectal cancer liver metastasis. J Surg Oncol. (2018) 118:68-76. doi: 10.1002/jso.25091

79. Chaput N, Louafi S, Bardier A, Charlotte F, Vailant JC, Ménégaux F, et al. Identification of $\mathrm{CD}^{+} \mathrm{CD}^{+} 5^{+} \mathrm{Foxp}^{+}$suppressive $\mathrm{T}$ cells in colorectal cancer tissue. Gut. (2009) 58:520-9. doi: 10.1136/gut.2008.158824

80. Blatner NR, Mulcahy MF, Dennis KL, Scholtens D, Bentrem DJ, Phillips JD, et al. Expression of ROR $\gamma \mathrm{t}$ marks a pathogenic regulatory $\mathrm{T}$ cell subset in human colon cancer. Sci Transl Med. (2012) 4:164ra159. doi: 10.1126/scitranslmed.3004566

81. Kryczek I, Wu K, Zhao E, Wei S, Vatan L, Szeliga W, et al. IL$17+$ regulatory $\mathrm{T}$ cells in the microenviroments of chronic inflammation and cancer. J Immunol. (2011) 186:4388-95. doi: 10.4049/jimmunol.10 03251
82. Korn T, Bettelli E, Oukka M, Kuchroo VK. IL-17 and Th17 cells. Annu Rev Immunol. (2009) 27:485-517. doi: 10.1146/annurev.immunol.021908.1 32710

83. Maxwell JR, Zhang Y, Brown WA, Smith CL, Byrne FR, Fiorino $M$, et al. Differential roles for interleukin23 and interleukin-17 in intestinal immunoregulation. Immunity. (2015) 43:739-50. doi 10.1016/j.immuni.2015. 08.019

84. Chung Y, Chang SH, Martinez GJ, Yang XO, Nurieva R, Kang HS, et al. Critical regulation of early Th17 cell differentiation by interleukin-1 signaling. Immunity. (2009) 30:576-87. doi: 10.1016/j.immuni.2009.02.007

85. Deng J, Galipeau J. B cells for cancer immunotherapy. Oncoimmunology. (2014) 3:e955702. doi: 10.4161/21624011.2014.9 55702

86. Kurashima Y, Kiyono H. Mucosal ecological network of epithelium and immune cells for gut homeostasis and tissue healing. Annu Rev Immunol. (2017) 35:119-147. doi: 10.1146/annurev-immunol-051116-0 52424

87. Magri G, Comerma L, Pybus M, Sintes J, Lligé D, Segura-Garzón $\mathrm{D}$, et al. Human secretory IgM emerges from plasma cell clonally related to gut memory $\mathrm{B}$ cells and targets highly diverse commensals. Immunity. (2017) 47:118-34.e8. doi: 10.1016/j.immuni.2017. 06.013

88. Nakatsu G, Li X, Zhou H, Sheng J, Wong SH, Wu WK, et al. Gut mucosal microbiome across stages of colorectal carcinogenesis. Nat Commun. (2015) 6:8727. doi: $10.1038 /$ ncomms 9727

89. Zirakzadeh AA, Marits P, Sherif A, Winqvist O. Multiplex B cell characterization in blood, lymph nodes, and tumors from patients with malignancies. J Immunol. (2013) 190:584755. doi: 10.4049/jimmunol.1203279

90. Berntsson J, Nodin B, Eberhard J, Micke P, Jirström K. Prognostic impact of tumour-infiltrating B cells and plasma cells in colorectal cancer. Int J Cancer. (2016) 139:1129-39. doi: 10.1002/ijc.30138

91. Shimabukuro-Vornhagen A, Schlößer HA, Gryschok L, Malcher J, Wennhold K, Garcia-Marquez M, et al. Characterization of tumor-associated B-cell subsets in patients with colorectal cancer. Oncotarget. (2014) 5:465164. doi: 10.18632/oncotarget.1701

92. Jobin G, Rodriguez-Suarez R, Betito K. Association between natural killer cell activity and colorectal cancer in high-risk subjects undergoing colonoscopy. Gastroenterology. (2017) 153:980-7. doi: 10.1053/j.gastro.2017. 06.009

93. Maccalli C, Scaramuzza S, Parmiani G. TNK cells $\left(\mathrm{NKD}_{2} \mathrm{D}^{+} \mathrm{CD} 8^{+}\right.$or $\mathrm{CD}^{+} \mathrm{T}$ lymphocytes) in the control of human tumors. Cancer Immunol Immunother. (2009) 58:801-8. doi: 10.1007/s00262-008-0635-X

94. Ferrari de Andrade L, Tay RE, Pan D, Luoma AM, Ito Y, et al. Antibody-mediated inhibition of MICA and MICB shedding promotes NK cell-driven tumor immunity. Science. (2018) 359:1537-542. doi: 10.1126/science.aao0505

95. Pugh SA, Harrison RJ, Primrose JN, Khakoo SI. T cell but not NK cells are associated with a favorable outcome for resected colorectal liver metastasis. BMC Cancer. (2014) 14:180. doi: 10.1186/1471-2407-14-180

96. Rescigno M. Intestinal dendritic cells. Adv Immunol. (2010) 107:10938. doi: 10.1016/B978-0-12-381300-8.00004-6

97. Legitimo A, Consolini R, Failli A, Orsini G, Spisni R. Dendritic cell defects in the colorectal cancer. Hum Vaccin Immunother. (2014) 10:322435. doi: 10.4161/hv.29857

98. Fu C, Jiang A. Dendritic cells and CD8 T cell immunity in tumor microenvironment. Front Immunol. (2018) 9:3059. doi: 10.3389/fimmu.2018.03059

99. Hildner K, Edelson BT, Purtha WE, Diamond M, Matsushita $H$, Kohyama $\mathrm{M}$, et al. Baft3 deficiency reveals a critical role for $\mathrm{CD} 8 \alpha^{+}$ dendritic cells in cytotoxic T cell immunity. Science. (2008) 322:1097100. doi: 10.1126/science.1164206

100. Sánchez-Paulete AR, Teijeira A, Cueto FJ, Garasa S, Pérez-Gracia JL, Sánchez-Arráez A, et al. Antigen cross-presentation and T-cell cross-priming in cancer immunology and immunotherapy. Ann Oncol. (2017) 28:xii44xii55. doi: 10.1093/annonc/mdx237 
101. Cavnar MJ, Turcotte S, Katz SC, Kuk D, Gönen M, Shia J, et al. Tumorassociated macrophage infiltration in colorectal cancer liver metastases is associated with better outcome. Ann Surg Oncol. (2017) 24:183542. doi: 10.1245/s10434-017-5812-8

102. Lee CC, Lin JC, Hwang WL, Kuo YJ, Chen HK, Tai SK, et al. Macrophagesecreted interleukin- 35 regulates cancer cell plasticity to facilitate metastatic colonization. Nat Commun. (2018) 9:3763. doi: 10.1038/s41467-018-0 6268-0

103. Sanmamed MF, Chen L. A paradigm shift in cancer immunotherapy: from enhancement to normalization. Cell. (2018) 175:31326. doi: 10.1016/j.cell.2018.09.035
Conflict of Interest: The authors declare that the research was conducted in the absence of any commercial or financial relationships that could be construed as a potential conflict of interest.

Copyright (c) 2020 Guo, Wang, Qiu, Pu and Chang. This is an open-access article distributed under the terms of the Creative Commons Attribution License (CC BY). The use, distribution or reproduction in other forums is permitted, provided the original author(s) and the copyright owner(s) are credited and that the original publication in this journal is cited, in accordance with accepted academic practice. No use, distribution or reproduction is permitted which does not comply with these terms. 